\title{
Wealth and Child Development: Differences in Associations by Family Income and Developmental Stage
}

\author{
PORTIA MILLER, TAMARA PODVYSOTSKA®, LAURA BETANCUR, \\ AND ELIZABETH VOTRUBA-DRZAL
}

\begin{abstract}
Wealth inequality is at a historic high in the United States. Yet little is known about the implications of wealth on children's development because research has focused mainly on the role of wealth in shaping outcomes in adulthood. Using data from the National Longitudinal Survey of Youth $(N=8,095)$, we examine how family wealth relates to achievement and behavior problems during early childhood, middle childhood, and adolescence. Further, we explore whether links between wealth and children's development vary by level of income and income volatility. Results show that wealth, controlling for income level and volatility, is uniquely related to both academic and behavioral development in early childhood, middle childhood, and adolescence. Moreover, evidence suggests that wealth plays a buffering role when it comes to protecting children's development from the deleterious effects of low family income, especially as children grow older.
\end{abstract}

Keywords: family wealth, family income, income volatility, child development, achievement, behavior problems

Economic disadvantage threatens children's development. Relative to their more advantaged peers, economically disadvantaged children exhibit lower academic and behavioral skills at the start of kindergarten (Garcia 2015). These disparities persist throughout formal schooling and predict low educational attainment, worse psychological functioning, and intergenerational transmission of low levels of income and wealth in adulthood (Duncan et al. 2007; Duncan and Magnuson 2011; GibsonDavis and Hill 2021, this issue; Heckman 2000). Accordingly, skills gaps have been the focus of considerable research and policy. Despite this attention, economic disparities in children's outcomes have grown over the past fifty years, even as racial-ethnic disparities have declined (Reardon 2011).

Portia Miller is a research associate in the Learning Research and Development Center at the University of Pittsburgh, United States. Tamara Podvysotska is a doctoral candidate in the Department of Psychology at the University of Pittsburgh, United States. Laura Betancur is a postdoctoral research associate at the Department of Human Development and Family Studies, lowa State University, United States. Elizabeth Votruba-Drzal is professor of psychology and a research scientist in the Learning Research and Development Center at the University of Pittsburgh, United States.

(C) 2021 Russell Sage Foundation. Miller, Portia, Tamara Podvysotska, Laura Betancur, and Elizabeth VotrubaDrzal. 2021. "Wealth and Child Development: Differences in Associations by Family Income and Developmental Stage." RSF: The Russell Sage Foundation Journal of the Social Sciences 7(3): 152-74. DOI: 10.7758/RSF.2021 7.3.07. Direct correspondence to: Portia Miller at plm11@pitt.edu, 521 Learning Research and Development Center, 3939 O'Hara St., Pittsburgh, PA 15213, United States.

Open Access Policy: RSF: The Russell Sage Foundation Journal of the Social Sciences is an open access journal. This article is published under a Creative Commons Attribution-NonCommercial-NoDerivs 3.0 Unported License. 
To date, much of the research and policy agendas aimed at remedying skills gaps has concentrated on how family income relates to disparities in children's outcomes. Much less attention has been paid to the implications of wealth even though wealth inequality is greater than income inequality in the United States (Saez 2017; Wolff 2017) and growth in wealth inequality has outpaced that of income inequality in families with children (GibsonDavis and Hill 2021, this issue). Indeed, levels of wealth inequality in the United States have reached highs not seen since the turn of the twentieth century (Gibson-Davis and Hill 2021, this issue; Yellen 2016). Median net worth has declined over the past thirty years as mean net worth has risen disproportionately, and the share of households with no wealth or in debt has grown (Pfeffer and Schoeni 2016). Moreover, low net wealth is particularly problematic in families with children (Gibson-Davis and Percheski 2018; Pfeffer and Schoeni 2016). This likely has implications for disparities in achievement and behavioral functioning, as several studies have linked wealth to children's development-primarily academic (see Diemer, Marchand, and Mistry 2020; Elliott, Destin, and Friedline 2011; Ream and Gottfried 2019; Shanks 2007; Yeung and Conley 2008). Understanding the role of wealth in academic and behavioral development may thus be key to reducing economic skills gaps. However, studies have not explored how wealth relates to children's outcomes across various developmental stages of childhood, controlling for other measures of family economic condition.

Using data from the National Longitudinal Survey of Youth (NLSY) and its child supplement (NLSY-CS), this study contributes to our knowledge of the associations between wealth and children's academic and behavioral development. Specifically, we examine how family wealth predicts reading and math achievement and internalizing and externalizing problems at three distinct periods of child development: early childhood; middle childhood; and adolescence. We explore whether wealth acts to buffer children from low levels of family income or high levels of income volatility. By considering the role of wealth in shaping children's development at different stages and how it interfaces with other dimension of family economic wellbeing, we hope to help shed light on the potential implications of widening wealth gaps for children's development.

\section{FRAMEWORKS FOR UNDERSTANDING THE ROLE OF WEALTH IN CHILDREN'S DEVELOPMENT}

Wealth, defined here as net worth (that is, assets minus debts) but operationalized in various ways as Christina Gibson-Davis and Heather Hill (2021) describe in the introduction to this issue, may affect children in a variety of ways. Drawing from fields of psychology, sociology, and economics, we rely on three theoretical frameworks for helping us conceptualize the role that wealth may play in shaping child development: resource and investment, family stress, and social or cultural capital. First, resource and investment perspectives posit that economic resources dictate families' abilities to invest in materials and experiences that produce better child outcomes, like educational activities, adequate health services, and good neighborhoods and schools (Becker 1991). As discussed in the introduction to this volume, wealth is an important economic resource that families use to invest in their children (GibsonDavis and Hill 2021). It can be accessed to provide cash resources or used as collateral for securing loans. Wealth is also a stock of resources and enables saving for future expenditures, such as college education (Ford and Thompson 2016; Grinstein-Weiss, Shanks, and Beverly 2014). Qualitative work by Thomas Shapiro (2005) shows how parents leverage their wealth to make life-changing investments in children, particularly in terms of residence in better neighborhoods and enrollment in better schools. Wealth can also generate nonwork income (such as interest or dividend income) without time spent working, which frees up parental time to be invested in enriching interactions with children (Becker 1991).

Next, models of family stress show that economic strain leads to increased psychological distress and interparental conflict. Parental distress and conflict are linked to harsher, more detached, and less nurturing, stimulating, and responsive parenting, which in turn predicts worse outcomes for children, such as increased 
internalizing and externalizing problems and less advanced cognitive and academic skills (Brotman et al. 2009; Chazan-Cohen et al. 2009; Farah et al. 2008; Shaw et al. 2001). Wealth can reduce economic strain by providing financial and psychological security against economic crises, especially in times of hardship, such as unemployment or family breakup (GibsonDavis and Hill 2021, this issue; Yeung and Hofferth 1998). Wealth also affects families' abilities to withstand financial shocks, such as a medical emergency (Ford and Thompson 2016). Moreover, studies have documented that families with negative wealth have heightened levels of stress due to "debt stress" (Brown, Taylor, and Price 2005; Drentea and Lavrakas 2000; Dunn and Mirzaie 2016): stress stemming from owing money, paying high interest rates, or dealing with collection agencies.

Last, wealth is the strongest determinant of class status (Conley 1999). It increases power, independence, and social and cultural capital, which provide positive personal and social effects on family and child well-being beyond those conferred by income alone (Bourdieu and Passeron 1990; Gibson-Davis and Hill 2021, this issue; Oliver and Shapiro 1995). Studies have documented how membership in the middle and upper classes provide families with an understanding of culturally significant cues and institutional know-how, change the way people think and behave, and expand the array of available opportunities (Lareau 2015). In turn, their children are exposed to opportunities and social and cultural capital that foster the acquisition of academic and behavioral skills that ungird future success (Bourdieu and Passeron 1990; Lareau 2015; Orr 2003). For example, Annette Lareau finds that middle- and upper-class parents teach children the "rules of the game" regarding how institutions such as schools operate and how to navigate them (Lareau 2015). As a result, when faced with problems, their children are more inclined to ask for help and have their needs met by these institutions than to become frustrated and give up or address issues in a suboptimal matter (Calarco 2014; Lareau 2015). These skills lead to better academic and behavioral outcomes (Calarco 2014). Wealthier children are also more likely to participate in extracurricular activities; indeed, in a recent study, wealth (not income) predicted total hours spent engaging in extracurricular activities, including those occurring within schools as well as nonschool extracurriculars (Weiniger, Lareau, and Conley 2015). Participation in extracurricular activities has been linked to both higher achievement and better behavioral outcomes (Covay and Carbonaro 2010; Metsäpalto and Pulkkinen 2012).

In addition to directly relating to child outcomes, wealth may interact with income level and income volatility to alter their links to development. A long literature has documented positive links between family income and children's development including achievement and behavior problems (Blau 1999; Gershoff et al. 2007; Reardon 2011). Much less research has explored how income volatility is related to child functioning, though recent studies have documented links between income volatility and behavior problems; in particular, income losses have been associated with increased externalizing and internalizing behavior problems (Miller et al. 2020; Miller and Votruba-Drzal 2017). Wealth acts to stabilize and enhance family income dynamics (Rauscher and Elliott 2016). For example, consider two low-income families with similar levels of annual income; a family with more wealth, that is, less debt or more assets, may have more money available for child investments if it has fewer debt obligations or less bills to pay because, for instance, the family owns its home or car. The wealthier family may also be able to borrow against assets to meet financial obligations. This may attenuate links between income level and child outcomes. In regard to volatility, as a stabilizer, wealth may reduce stress from economic uncertainty or income loss, which would weaken negative links between volatility and children's self-regulatory and attentional abilities and, in turn, academic and behavioral development (Blair and Raver 2016; Evans et al. 2005; PalaciosBarrios and Hanson 2019; Wadsworth et al. 2016). Similarly, two families experiencing income volatility may have different outcomes if one has wealth, like savings or assets to borrow against, that can be leveraged to supplement their economic resources in times of volatility. In these ways, wealth may buffer children from the negative ramifications of low income levels 
or high income volatility on children's achievement and behavior.

\section{LINKS BETWEEN WEALTH}

\section{AND CHILD OUTCOMES}

The literature examining associations between family wealth and children's well-being is growing, the majority of which is focused on academic outcomes. In particular, several studies have explored relations between wealth and achievement, with results varying widely across studies. Inconsistent results may be due to differences in wealth definitions, use of samples varying in age and developmental stage, or differences in the extent to which models account for other aspects of family economic circumstances. Many of these studies draw data from the NLSY and find positive links between wealth and achievement (Mayer 1997; Orr 2003; Zhan 2006). Others draw data from the Panel Study of Income Dynamics (PSID). For example, Jean Yeung and Dalton Conley (2008) find that debt predicts reading and math in early childhood (ages three through five) and that net worth predicts math and liquid assets predict reading during middle childhood (ages six through twelve). Also using PSID data but collapsing across ages three through twelve, Trina Shanks (2007) does not observe associations between wealth and reading skills, but does find that debt and net worth predict math. Other studies find null effects of wealth on achievement. For instance, a study using NLSY data and examining reading skills finds no association between net worth and reading (Phillips et al. 1998). Studies using other data similarly find no associations between wealth and achievement. These include findings of null effects of wealth on academic scores during adolescence in the National Educational Longitudinal Study (Easton-Brooks and Davis 2007) and of savings on high school grades in the National Survey of Families and Households (Zhan and Sherraden 2003). Across the literature, some evidence suggests that links between wealth and math scores are stronger and more consistent than associations between wealth and reading (Elliott, Destin, and Friedline 2011).

Beyond studies examining family wealth and achievement, the research on wealth and other aspects of child development, such as social and emotional functioning, is quite limited. Virtually no studies have examined whether wealth relates to children's behavioral development; however, proximal experiences related to wealth's associations with achievement may also shape children's problem behavior, and the mechanisms driving wealth-achievement relations operate similarly for behavior. One notable exception is Shanks's 2007 study. Using PSID data, she finds that higher net worth predicted fewer behavior problems in a sample of children ranging in age from three through twelve. Another informative study uses NLSY data to look at links between debt and behavior problems (Berger and Houle 2016). Lawrence Berger and Jason Houle (2016) find that family debt is associated with more problem behavior. Studies have also linked childhood wealth to high school dropout (Pfeffer 2018). Additionally, some studies link childhood wealth to a variety of outcomes in adulthood, especially educational attainment (Elliott, Destin, and Friedline 2011; Karagiannaki 2017), adult labormarket outcomes (Karagiannaki 2017), and adult mental health (Lê-Scherban, Brenner, and Schoeni 2016).

\section{DEVELOPMENTAL DIFFERENCES}

IN THE ROLE OF WEALTH

Studies document developmental differences in links between income and child outcomes (Miller et al. 2020; Votruba-Drzal 2006). It thus seems reasonable to expect that wealth may have differential associations with academic achievement and behavior over the course of development. For several reasons, we hypothesize that its role will become more pronounced as children age. First, adolescents are more aware of their families' financial situations (Orr 2003; Yeung and Conley 2008). Plans to attend college may wane as adolescents process the cost of higher education and their families' ability to pay for it, which could have a negative impact on achievement. In addition, parental expectations for children's educational achievement and attainment, which are positively linked to wealth (Shanks and Destin 2009; Zhan 2006), are likely to intensify as children get older. As college approaches, parents and teachers of children from wealthier families likely begin expressing more demanding and 
concrete expectations for the children when it comes to academics or behavior that puts them on the path to top colleges and careers.

Second, as children age, their contact with environments outside the home increases. Thus, to the extent that wealth buys access to better schools and neighborhoods, wealth effects may grow with age as children spend more time in school, with peers, and in their communities. The social and cultural capital that comes with wealth and the neighborhoods and schools it can buy becomes more salient as children age. Wealthier parents can access social and cultural capital to connect their children to networks that put children on trajectories of academic success and guide them away from risky behaviors that may indulge sensationseeking tendencies that manifest during adolescence. Moreover, with increased exposure to peers and adults outside of the home comes increased awareness of stereotypes and gaps between the experiences of wealthy versus nonwealthy families (Heberle and Carter 2015), which may shape mental health and future goals and thus achievement and behavior.

Last, wealth gaps in children's behavior problems may become more pronounced as children age because of the developmental trajectories of externalizing and internalizing disorders. Externalizing problems are relatively normative during early childhood, with most children desisting from these behaviors as they move into middle childhood and adolescence (Lewis and Rudolph 2014). Externalizing behaviors exhibited in middle childhood and early adolescence are associated with more serious consequences for children's trajectories over the life course. During these times, when externalizing becomes nonnormative, wealth may expose children to sociocultural norms that discourage externalizing behaviors. Internalizing problems, on the other hand, tend to be lower in early childhood. Increases in internalizing disorders occur at the onset of puberty and around the transition to adulthood, and this may be especially pronounced for children who experience low levels of wealth (Lewis and Rudolph 2014). Coupling the normal trajectory of internalizing problems with stereotyping and negative feelings about having less wealth than their peers during early adolescence suggests that wealth effects on internalizing would grow with age, with the largest effects visible at adolescence (Heberle and Carter 2015). Moreover, when children do experience problem behavior, wealth helps families access mental and behavioral health services to promote more positive behavioral development and can protect children against the more serious consequences of their behaviors (Luthar and Barkin 2012).

\section{RESEARCH AIMS}

Limitations in the current wealth literature preclude a full understanding of its role in child development. First, although these studies generally control for annual family income, they do not control for income volatility. This is problematic given that wealth may stabilize economic resources during times of income volatility (Rauscher and Elliott 2016), since families may draw from or borrow against assets to supplement lost income. Thus, without also exploring income volatility, it is unclear whether all or some of the association between wealth and child outcomes is attributable to less income volatility. Along those lines, wealth may act as a buffer in times of lower income or high income volatility (Rauscher and Elliott 2016). For this reason, wealth may moderate links between income level and volatility and child outcomes. No studies have explored interactions between income and wealth.

Second, in the current literature focused on wealth and children's development, the age at which children's outcomes were measured varies widely across studies. As discussed, family wealth may have varying effects on achievement depending on child age. Moreover, some of the studies are cross-sectional and thus do not include information on income and wealth at earlier stages of children's lives (Orr 2003; Yeung and Conley 2008; Zhan and Sherradan 2003). Studies show that economic conditions in early childhood continue to affect children's outcomes into adolescence (Magnuson and Votruba-Drzal 2008). Thus, studies that do not consider prior levels of wealth may underestimate associations between wealth and development. Last, the literature on wealth and child 
development has focused on its associations with achievement. Links between wealth and behavior problems remain unclear despite theoretical reasons to expect associations.

To address these limitations, this study has two aims. First, it looks at the associations between cumulative wealth (measured from birth through the time of outcome) and children's achievement and behavior at three distinct developmental periods-early childhood (age four to five), middle childhood (age nine to ten), and adolescence (age thirteen to fourteen)-while controlling for two other dimensions of family economic circumstances, income level and volatility. Second, it explores the stabilizing role of family wealth by considering whether wealth moderates links between both income level and income volatility and child outcomes.

\section{METHODS}

Data were drawn from the National Longitudinal Survey of Youth 1979 (NLSY79) and its child supplement (NLSY-CS). The Bureau of Labor Statistics initiated the NLSY in 1979 to gather longitudinal data on the labor-market activities and other significant life events of young men and women in the United States. The original sample consisted of a nationally representative group of 12,868 men and women between the ages of fourteen and twenty-two, with an oversample of poor and minority individuals. The NLSY gathered income, employment, educational, and other data on the sample annually until 1994 at which point data were collected biennially. In 1986, the NLSY introduced the child supplement, a separate survey of the biological children from the NLSY female participants. This study increased the child-specific information collected and followed children in the NLSY-CS until age fourteen. Biennially since 1986, children of the NLSY79 mothers have been interviewed and children's cognitive, physical, and behavioral development has been assessed. As of 2014, a total of 11,521 children have been identified as having been born to the original 6,283 NLSY female respondents. The NLSY-CS includes direct assessments of children's academic achievement and parent reports of behavioral development. This study uses eleven birth cohorts of children with data from early childhood through age thirteen and fourteen. Missing data on variables included in this study ranged from a low of 0 percent for many of the demographic variables, such as gender, birth cohort, and race, to a high of about 44 percent of the data missing for the direct assessments of achievement. Children with full data on the family economic circumstances of interest totaled 8,095. For them, we imputed all other missing data using multiple imputation by chained equations implemented in Stata to create ten imputed datasets (Royston 2005). Our final analytic sample was 8,095 across all models.

\section{Child Outcome Measures}

Behavioral functioning was measured using the Behavior Problem Index (BPI) (Peterson and Zill 1986), which measures the frequency and type of behavioral problems for children ages four through fourteen. The total index score is based on parents' answer to questions about their children's behaviors over the prior three months on a 3 -point ordinal scale $(0=$ not true, 1 = sometimes true, 2 = often true). Examples of these items include whether the child is impulsive, is disobedient at home, is cruel to others, easily loses his or her temper, is fearful or anxious, is sad or depressed, or is withdrawn. Two factors tapping children's internalizing behaviors and externalizing behaviors have been identified in the BPI. These factors have been shown to be reliable and valid in prior research (Center for Human Resource Research 2002). Independent measures of internalizing (six items, $\alpha=0.67-0.78$ ) and externalizing (fourteen items, $\alpha=0.84-0.89$ ) behavioral problems were constructed using only the items that were asked consistently across all ages so that measures were consistent over time. The behavioral outcomes were standardized within each developmental stage to ease interpretation of results.

Peabody Individual Achievement Tests (PIAT) were used to measure academic achievement of children at early childhood (age five to six), middle childhood (age nine to ten), and adolescence (age thirteen to fourteen). This study focuses on mathematics and reading 
skills, which were measured through the Mathematics, Reading Recognition, and Reading Comprehension subtests. Each of the subtests measures children's academic skills according to the educational expectation by child age and grade (Markwardt 1997). The PIAT Mathematics subtest is an age-normed test of mathematical reasoning and ability for children. It consists of eighty-four items measuring early skills such as recognizing numbers and advanced mathematic concepts such as geometry and trigonometry. The measure of reading skills was created by averaging the Reading Recognition and Comprehension subtests. Reading Recognition measures letter and word recognition and pronunciation (eighty-four items). The Reading Comprehension test measures the children's ability to derive meaning from what is read. The test was taken by children who scored at least 19 points at the Reading Recognition test. The test consists of sixty-six sentences that the child reads silently and then choses the picture that best describes the sentence meaning. Both PIAT subtests have been shown to be reliable, with a test-retest reliability that ranges from 0.73 to 0.84 , and with good cross-year reliability (Baker et al. 1993). All academic outcomes were standardized within each developmental stage.

\section{Family Economic Circumstances}

The measure of wealth used in this study is based on the total net wealth variable calculated by the NLSY. It was calculated as the difference between assets and debts (and thus can have positive, zero, and negative values). Information collected included reports on assets like home value, value of businesses and real estate, vehicles, IRAs, 401(k) and 403(b) retirement plans, stocks, bonds, mutual funds, cash savings, and other assets like jewelry or collections, and reports of debts like mortgages or other residential debt, debt on vehicles, and credit card and student loan debt. To account for economies of scale, wealth was adjusted for the square root of household size (Gibson-Davis and Percheski 2018). Given that the wealth data were skewed and initial exploratory analyses showed nonlinearities in links between wealth and child outcomes, we tested two different nonlinear specifications of the wealth variable: the natural log of wealth and wealth quintiles (with dummy variables indicating the quintile to which the family belonged). To log transform the wealth variable, we added a constant to the wealth value to deal with negative and zero values (which cannot be log transformed). Results for logged wealth and wealth quartiles were similar; for simplicity's sake, we present models with the log of wealth except where results differed.

To measure income level and income volatility, each year (or every other year since 1994), respondents were asked to report the income received by all household members in the prior calendar year from wages, salaries, and business earnings. Family income for each year was converted to 2013 inflation-adjusted dollars so that income was comparable across years. Because research has shown that cumulative income is a stronger predictor of children's outcomes than income in any period (Mayer 1997), we created income measures that drew data from the year prior to birth through age of the predicted outcome. Income was also adjusted for family size in the same way as wealth so that income and wealth coefficients were comparable. Income level was transformed by the natural $\log$ to correct for skew (first adding a constant to values to shift the distribution so there were no zero values) and because prior literature has shown that income increases tend to matter more for families with lower incomes.

Income volatility measures were created for each developmental period by calculating the difference in income between two consecutive years (subtracting previous income from income earned two years later). We used the twoyear span because after 1994, income was only measured every two years and we wanted a consistent measure over time. Next, we created dichotomous indicators reflecting whether the family had a negative income shock of at least 25 percent in the two-year span. We chose the 25 percent cutoff based on income volatility research (Hardy 2014; Miller et al. 2020); models included negative income shocks only also based on our prior work (Miller et al. 2020; Miller and Votruba-Drzal 2017) and empirical analyses with these data showing that only negative income shocks, not positive shocks, related to child outcomes. Finally, the volatility measure was accumulated from the year before 
birth through the predicted outcome in each model in order to denote how many times the family experienced an income loss of at least 25 percent.

As to child and family covariates, demographic characteristics that could influence economic fluctuations and child outcomes were included in the models. Child covariates included child age in months, gender (female reference group), and race-ethnicity, categorized as Latinx, black, white, or other racialethnic group (Latinx being the reference group). Using a series of dummy variables, we also controlled for the cohort in which the child was born. Family covariates included the number of children under the age of eighteen living in the house, whether the family lived in an urban or rural area, age of the mother at the birth of the first child, whether the mother was married, and the number of weeks the mother has been unemployed in the past calendar year. The number of years of maternal education was coded as a continuous variable that ranged from zero to twenty. We also controlled for mothers' score on the Air Force Qualification Test (AFQT), which measures aptitude on a variety of intellectual tasks, such as arithmetic reasoning, word knowledge, paragraph comprehension, and numerical operations. All time-varying characteristics were averaged across waves from birth to the predicted outcome age.

\section{Analytic Plan}

Our first aim was to examine the main effects of wealth on reading and math achievement and internalizing and externalizing behavior across three developmental stages: early childhood (age five and six), middle childhood (age nine and ten), and adolescence (age thirteen and fourteen). To do so, we estimated separate ordinary least squares regressions for each developmental stage to predict each outcome with wealth, controlling for other aspects of economic circumstances. Thus, the child outcome was predicted by wealth, income level, income volatility, and all covariates. Our second aim was to explore whether wealth moderated the effects of income level and income volatility on child development. For this, we reestimated the models with the addition of in- teractions between wealth and income level and income volatility.

\section{RESULTS}

Table 1 presents weighted descriptive statistics for the full sample and broken out by developmental stage. Descriptive statistics show that the sample is diverse in terms of race-ethnicity, economic conditions, and child outcomes. In addition, the difference between the mean and median of wealth and family income is large, illustrating the skew in these variables. When examining the development of behavioral problems over time, on average, children's internalizing problems slightly increased and externalizing problems generally decreased. Children, on average, gained math and reading skills over time.

\section{Associations Between Wealth and Development}

Results of analyses associating wealth with early childhood achievement and behavioral functioning are presented in table 2. Holding annual income and income volatility constant, wealth was related to externalizing problems and both math and reading scores. Every log unit increase in wealth (about a 2.7 -fold increase) was associated with reductions in externalizing behavior problems of 0.30 of a standard deviation (SD). This same increase in wealth was also linked to higher achievement scores $(0.23 \mathrm{SD}$ for math and $0.17 \mathrm{SD}$ for reading). Analyses using wealth quintiles revealed some links between family wealth and internalizing problems (see table 4). Children in the first and second wealth quintile had higher levels of internalizing problems than those in the third, fourth, and fifth quintiles.

Table 3 presents the results of models predicting middle childhood outcomes with family wealth. Wealth was related to reduced behavior problems and higher achievement even after controlling for income level and volatility, plus numerous other child and family characteristics. Specifically, log unit increases in family wealth were related to decreases in internalizing and externalizing of 0.18 SD and 0.19 SD, respectively, and higher scores on math and reading assessments $(0.23 \mathrm{SD}$ and $0.16 \mathrm{SD}$, respectively). Analyses using wealth quintiles re- 
Table 1. Descriptive Statistics $(N=8,095)$

\begin{tabular}{|c|c|c|c|c|c|c|}
\hline \multirow[b]{2}{*}{ Variable } & \multicolumn{2}{|c|}{ Early Childhood } & \multicolumn{2}{|c|}{ Middle Childhood } & \multicolumn{2}{|c|}{ Adolescence } \\
\hline & $\begin{array}{c}\text { Mean or } \\
\text { Percent } \\
\text { (SD) }\end{array}$ & Median & $\begin{array}{c}\text { Mean or } \\
\text { Percent } \\
\text { (SD) }\end{array}$ & Median & $\begin{array}{l}\text { Mean or } \\
\text { Percent } \\
\text { (SD) }\end{array}$ & Median \\
\hline \multicolumn{7}{|l|}{ Child outcomes } \\
\hline Internalizing & $\begin{array}{l}1.10 \\
(1.54)\end{array}$ & & $\begin{array}{c}1.41 \\
(1.82)\end{array}$ & & $\begin{array}{c}1.40 \\
(1.95)\end{array}$ & \\
\hline Externalizing & $\begin{array}{c}6.07 \\
(4.62)\end{array}$ & & $\begin{array}{c}6.04 \\
(4.96)\end{array}$ & & $\begin{array}{c}5.91 \\
(5.07)\end{array}$ & \\
\hline PIAT Mathematics & $\begin{array}{c}14.28 \\
(5.72)\end{array}$ & & $\begin{array}{c}42.02 \\
(10.89)\end{array}$ & & $\begin{array}{c}55.43 \\
(11.85)\end{array}$ & \\
\hline PIAT Reading and Comprehension & $\begin{array}{c}15.71 \\
(5.69)\end{array}$ & & $\begin{array}{c}42.02 \\
(10.88)\end{array}$ & & $\begin{array}{c}56.72 \\
(12.26)\end{array}$ & \\
\hline \multicolumn{7}{|l|}{ Economic circumstances } \\
\hline Family wealth & $\begin{array}{c}\$ 95,606 \\
(\$ 269,312)\end{array}$ & $\$ 15,123$ & $\begin{array}{c}\$ 112,420 \\
(\$ 290,657)\end{array}$ & $\$ 21,393$ & $\begin{array}{c}\$ 126,372 \\
(\$ 432,820)\end{array}$ & $\$ 26,838$ \\
\hline Family wealth weighted by family size & $\begin{array}{c}\$ 48,034 \\
(\$ 135,344)\end{array}$ & & $\begin{array}{c}\$ 55,873 \\
(\$ 146,083)\end{array}$ & & $\begin{array}{c}\$ 62,553 \\
(\$ 151,704)\end{array}$ & \\
\hline Family income & $\begin{array}{c}\$ 49,362 \\
(\$ 55,280)\end{array}$ & $\$ 35,918$ & $\begin{array}{l}\$ 51,449 \\
(\$ 55,637)\end{array}$ & $\$ 38,307$ & $\begin{array}{c}\$ 52,782 \\
(\$ 55,651)\end{array}$ & $\$ 39,480$ \\
\hline Family income weighted by family size & $\begin{array}{c}\$ 26,283 \\
(\$ 29,969)\end{array}$ & $\$ 19,066$ & $\begin{array}{c}\$ 26,856 \\
(\$ 29,244)\end{array}$ & $\$ 20,172$ & $\begin{array}{c}\$ 27,324 \\
(\$ 28,892)\end{array}$ & $\$ 20,783$ \\
\hline Negative income shocks & $\begin{array}{c}0.49 \\
(0.50)\end{array}$ & & $\begin{array}{l}0.82 \\
(0.72)\end{array}$ & & $\begin{array}{l}1.09 \\
(0.89)\end{array}$ & \\
\hline Child gender: male & $50.6 \%$ & & $50.6 \%$ & & $50.6 \%$ & \\
\hline Child age at assessment (years) & $\begin{array}{l}5.5 \\
(0.50)\end{array}$ & & $\begin{array}{l}9.5 \\
(1.71)\end{array}$ & & $\begin{array}{l}13.5 \\
(0.50)\end{array}$ & \\
\hline Mother's race: Latino & $20.2 \%$ & & $20.2 \%$ & & $20.2 \%$ & \\
\hline Black & $26.9 \%$ & & $26.9 \%$ & & $26.9 \%$ & \\
\hline Other & $52.9 \%$ & & $52.9 \%$ & & $52.9 \%$ & \\
\hline Percentage of waves mother is married & $68.2 \%$ & & $66.9 \%$ & & $66.0 \%$ & \\
\hline Mother is employed & $81.7 \%$ & & $83.3 \%$ & & $84.2 \%$ & \\
\hline Household is urban & $76.4 \%$ & & $74.8 \%$ & & $73.8 \%$ & \\
\hline Mother's years of education & $\begin{array}{r}12.55 \\
(2.38)\end{array}$ & & $\begin{array}{c}12.61 \\
(2.39)\end{array}$ & & $\begin{array}{l}12.65 \\
(2.39)\end{array}$ & \\
\hline Mother's education squared & $\begin{array}{c}162.78 \\
(60.74)\end{array}$ & & $\begin{array}{l}164.3 \\
(61.00)\end{array}$ & & $\begin{array}{c}165.43 \\
(61.34)\end{array}$ & \\
\hline AFQT & $\begin{array}{c}39,395 \\
(28,197)\end{array}$ & & $\begin{array}{c}39,395 \\
(28,197)\end{array}$ & & $\begin{array}{c}39,395 \\
(28,197)\end{array}$ & \\
\hline Maternal age at birth of first child & $\begin{array}{r}22.45 \\
(4.91)\end{array}$ & & $\begin{array}{r}22.45 \\
(4.91)\end{array}$ & & $\begin{array}{r}22.45 \\
(4.91)\end{array}$ & \\
\hline Number of children in house & $\begin{array}{c}2.07 \\
(1.06)\end{array}$ & & $\begin{array}{c}2.23 \\
(1.05)\end{array}$ & & $\begin{array}{c}2.26 \\
(1.03)\end{array}$ & \\
\hline
\end{tabular}

Source: Authors' calculations from the NLSY. 
Table 2. Early Childhood Outcomes Predicted By Family Economic Characteristics

\begin{tabular}{|c|c|c|c|c|}
\hline Predictors & $\begin{array}{l}\text { Internalizing } \\
\text { Coef. } \\
\text { (SE) }\end{array}$ & $\begin{array}{l}\text { Externalizing } \\
\text { Coef. } \\
\text { (SE) }\end{array}$ & $\begin{array}{l}\text { Math } \\
\text { Coef. } \\
\text { (SE) }\end{array}$ & $\begin{array}{l}\text { Reading } \\
\text { Coef. } \\
\text { (SE) }\end{array}$ \\
\hline Income & $\begin{array}{l}-0.04^{* * *} \\
(0.01)\end{array}$ & $\begin{array}{l}-0.03^{* * *} \\
(0.01)\end{array}$ & $\begin{array}{l}0.02^{* * *} \\
(0.01)\end{array}$ & $\begin{array}{c}0.02^{*} \\
(0.01)\end{array}$ \\
\hline Income shock & $\begin{array}{c}0.03 \\
(0.03)\end{array}$ & $\begin{array}{c}0.06^{*} \\
(0.03)\end{array}$ & $\begin{array}{l}-0.09^{* *} \\
(0.03)\end{array}$ & $\begin{array}{c}-0.07^{*} \\
(0.03)\end{array}$ \\
\hline Wealth & $\begin{array}{c}-0.10 \\
(0.06)\end{array}$ & $\begin{array}{l}-0.27^{* * *} \\
(0.06)\end{array}$ & $\begin{array}{l}0.19^{* *} \\
(0.07)\end{array}$ & $\begin{array}{l}0.20^{* * *} \\
(0.06)\end{array}$ \\
\hline Black & $\begin{array}{c}-0.03 \\
(0.04)\end{array}$ & $\begin{array}{c}-0.02 \\
(0.04)\end{array}$ & $\begin{array}{l}-0.04 \\
(0.04)\end{array}$ & $\begin{array}{l}0.23^{* * *} \\
(0.04)\end{array}$ \\
\hline Other & $\begin{array}{l}-0.00 \\
(0.04)\end{array}$ & $\begin{array}{l}0.09^{* *} \\
(0.03)\end{array}$ & $\begin{array}{l}0.18^{* * *} \\
(0.04)\end{array}$ & $\begin{array}{c}0.02 \\
(0.04)\end{array}$ \\
\hline Marital status & $\begin{array}{c}-0.05 \\
(0.04)\end{array}$ & $\begin{array}{l}-0.12^{* *} \\
(0.04)\end{array}$ & $\begin{array}{c}0.00 \\
(0.04)\end{array}$ & $\begin{array}{c}0.07^{*} \\
(0.03)\end{array}$ \\
\hline AFQT & $\begin{array}{l}-0.08^{* * *} \\
(0.02)\end{array}$ & $\begin{array}{c}-0.02 \\
(0.02)\end{array}$ & $\begin{array}{l}0.16^{* * *} \\
(0.02)\end{array}$ & $\begin{array}{l}0.19^{* * *} \\
(0.02)\end{array}$ \\
\hline Female & $\begin{array}{c}-0.02 \\
(0.02)\end{array}$ & $\begin{array}{l}-0.20 * * * \\
(0.02)\end{array}$ & $\begin{array}{l}0.09 * * * \\
(0.03)\end{array}$ & $\begin{array}{l}0.21^{* * *} \\
(0.02)\end{array}$ \\
\hline Mother's education & $\begin{array}{c}-0.10^{* *} \\
(0.03)\end{array}$ & $\begin{array}{l}-0.11^{* * *} \\
(0.03)\end{array}$ & $\begin{array}{c}0.04 \\
(0.04)\end{array}$ & $\begin{array}{l}0.09^{* *} \\
(0.03)\end{array}$ \\
\hline Mother's education squared & $\begin{array}{l}0.00^{* *} \\
(0.00)\end{array}$ & $\begin{array}{c}0.00^{*} \\
(0.00)\end{array}$ & $\begin{array}{c}0.00 \\
(0.00)\end{array}$ & $\begin{array}{c}-0.00 \\
(0.00)\end{array}$ \\
\hline Mother's employment & $\begin{array}{l}-0.06 \\
(0.05)\end{array}$ & $\begin{array}{c}-0.14^{* *} \\
(0.04)\end{array}$ & $\begin{array}{c}0.02 \\
(0.05)\end{array}$ & $\begin{array}{c}0.08 \\
(0.05)\end{array}$ \\
\hline Number of children & $\begin{array}{l}-0.00 \\
(0.01)\end{array}$ & $\begin{array}{l}-0.05^{* * *} \\
(0.01)\end{array}$ & $\begin{array}{l}-0.07^{* * *} \\
(0.02)\end{array}$ & $\begin{array}{l}-0.14^{* * *} \\
(0.02)\end{array}$ \\
\hline Urbanicity & $\begin{array}{c}-0.08^{*} \\
(0.03)\end{array}$ & $\begin{array}{c}-0.05 \\
(0.03)\end{array}$ & $\begin{array}{c}0.04 \\
(0.03)\end{array}$ & $\begin{array}{l}0.09^{* *} \\
(0.03)\end{array}$ \\
\hline Mother's age at birth & $\begin{array}{c}0.01^{*} \\
(0.00)\end{array}$ & $\begin{array}{c}-0.00 \\
(0.00)\end{array}$ & $\begin{array}{c}-0.00 \\
(0.00)\end{array}$ & $\begin{array}{c}-0.01^{+} \\
(0.00)\end{array}$ \\
\hline Constant & $\begin{array}{l}2.42^{* *} \\
(0.81)\end{array}$ & $\begin{array}{l}5.35^{* * *} \\
(0.79)\end{array}$ & $\begin{array}{l}-3.33^{* * *} \\
(0.87)\end{array}$ & $\begin{array}{l}-3.60^{* * *} \\
(0.73)\end{array}$ \\
\hline
\end{tabular}

Source: Authors' calculations from the NLSY.

Note: $\mathrm{N}=8,095$. Standard errors in parentheses. Child cohort was included in the model but not presented for parsimony.

${ }^{+} p<.1 ;{ }^{*} p<.05 ;{ }^{* *} p<.01 ;{ }^{* * *} p<.001$

vealed some links between family wealth and internalizing problems (table 4). Children in the first wealth quintile had higher levels of internalizing problems than children in the second, third, fourth, and fifth quintiles.

Last, the results of models predicting adolescent outcomes with family wealth are presented in table 5 . Links between family wealth and externalizing, math, and reading were observed. Wealth was negatively related to externalizing problems $(0.18 \mathrm{SD}$ reduction per $\log$ increase in wealth), and positively linked to math and reading achievement (respectively, 0.29 SD and 0.21 SD increases per log unit increase in wealth). Much as in early stages, models using wealth quintiles (see table 4) showed 
Table 3. Middle Childhood Outcomes Predicted by Family Economic Characteristics

\begin{tabular}{|c|c|c|c|c|}
\hline Predictors & $\begin{array}{l}\text { Internalizing } \\
\text { Coef. } \\
\text { (SE) }\end{array}$ & $\begin{array}{l}\text { Externalizing } \\
\text { Coef. } \\
\text { (SE) }\end{array}$ & $\begin{array}{l}\text { Math } \\
\text { Coef. } \\
\text { (SE) }\end{array}$ & $\begin{array}{l}\text { Reading } \\
\text { Coef. } \\
\text { (SE) }\end{array}$ \\
\hline Income & $\begin{array}{l}-0.05^{\star * *} \\
(0.01)\end{array}$ & $\begin{array}{l}-0.03^{* * *} \\
(0.01)\end{array}$ & $\begin{array}{l}0.03^{* * *} \\
(0.01)\end{array}$ & $\begin{array}{l}0.03^{* * *} \\
(0.01)\end{array}$ \\
\hline Income shock & $\begin{array}{c}0.04^{*} \\
(0.02)\end{array}$ & $\begin{array}{c}0.01 \\
(0.02)\end{array}$ & $\begin{array}{c}-0.01 \\
(0.02)\end{array}$ & $\begin{array}{l}-0.01 \\
(0.02)\end{array}$ \\
\hline Wealth & $\begin{array}{l}-0.18^{* *} \\
(0.06)\end{array}$ & $\begin{array}{l}-0.19^{* *} \\
(0.07)\end{array}$ & $\begin{array}{l}0.23^{* * *} \\
(0.06)\end{array}$ & $\begin{array}{l}0.16^{* *} \\
(0.06)\end{array}$ \\
\hline Black & $\begin{array}{c}-0.09^{*} \\
(0.04)\end{array}$ & $\begin{array}{c}0.00 \\
(0.04)\end{array}$ & $\begin{array}{l}-0.13^{* * *} \\
(0.04)\end{array}$ & $\begin{array}{l}-0.09^{* *} \\
(0.03)\end{array}$ \\
\hline Other & $\begin{array}{c}0.02 \\
(0.03)\end{array}$ & $\begin{array}{l}0.11^{* *} \\
(0.04)\end{array}$ & $\begin{array}{c}0.10^{*} \\
(0.04)\end{array}$ & $\begin{array}{c}0.02 \\
(0.03)\end{array}$ \\
\hline Marital status & $\begin{array}{l}-0.13^{* * *} \\
(0.04)\end{array}$ & $\begin{array}{l}-0.18^{* * *} \\
(0.04)\end{array}$ & $\begin{array}{c}0.01 \\
(0.03)\end{array}$ & $\begin{array}{l}0.10^{* *} \\
(0.03)\end{array}$ \\
\hline AFQT & $\begin{array}{c}0.01 \\
(0.02)\end{array}$ & $\begin{array}{c}0.02 \\
(0.02)\end{array}$ & $\begin{array}{l}0.24^{* * *} \\
(0.02)\end{array}$ & $\begin{array}{l}0.26^{* * *} \\
(0.02)\end{array}$ \\
\hline Female & $\begin{array}{l}-0.08^{* *} \\
(0.02)\end{array}$ & $\begin{array}{l}-0.27^{* * *} \\
(0.03)\end{array}$ & $\begin{array}{c}-0.03 \\
(0.02)\end{array}$ & $\begin{array}{l}0.17^{* * *} \\
(0.02)\end{array}$ \\
\hline Mother's education & $\begin{array}{l}-0.13^{* * *} \\
(0.03)\end{array}$ & $\begin{array}{c}-0.11^{* *} \\
(0.04)\end{array}$ & $\begin{array}{c}0.03 \\
(0.03)\end{array}$ & $\begin{array}{c}0.05^{+} \\
(0.03)\end{array}$ \\
\hline Mother's education squared & $\begin{array}{l}0.00^{* * *} \\
(0.00)\end{array}$ & $\begin{array}{c}0.00^{*} \\
(0.00)\end{array}$ & $\begin{array}{c}0.00 \\
(0.00)\end{array}$ & $\begin{array}{c}-0.00 \\
(0.00)\end{array}$ \\
\hline Mother's employment & $\begin{array}{c}-0.04 \\
(0.07)\end{array}$ & $\begin{array}{l}-0.22^{* * *} \\
(0.06)\end{array}$ & $\begin{array}{c}-0.06 \\
(0.06)\end{array}$ & $\begin{array}{l}0.05 \\
(0.06)\end{array}$ \\
\hline Number of children & $\begin{array}{c}-0.02^{+} \\
(0.01)\end{array}$ & $\begin{array}{l}-0.05^{* *} \\
(0.01)\end{array}$ & $\begin{array}{l}-0.06^{* * *} \\
(0.01)\end{array}$ & $\begin{array}{l}-0.12^{* * *} \\
(0.01)\end{array}$ \\
\hline Urbanicity & $\begin{array}{c}-0.05 \\
(0.04)\end{array}$ & $\begin{array}{c}-0.05 \\
(0.04)\end{array}$ & $\begin{array}{c}0.06^{+} \\
(0.03)\end{array}$ & $\begin{array}{c}0.03 \\
(0.03)\end{array}$ \\
\hline Mother's age at birth & $\begin{array}{c}0.00 \\
(0.00)\end{array}$ & $\begin{array}{l}-0.00 \\
(0.00)\end{array}$ & $\begin{array}{c}-0.00 \\
(0.00)\end{array}$ & $\begin{array}{c}-0.00 \\
(0.00)\end{array}$ \\
\hline Constant & $\begin{array}{l}4.02^{* * *} \\
(0.78)\end{array}$ & $\begin{array}{l}4.62^{* * *} \\
(0.89)\end{array}$ & $\begin{array}{c}-3.46^{* * *} \\
(0.758)\end{array}$ & $\begin{array}{l}-2.84^{* * *} \\
(0.73)\end{array}$ \\
\hline
\end{tabular}

Source: Authors' calculations from the NLSY.

Note: $\mathrm{N}=8,095$. Standard errors in parentheses. Child cohort was included in the model but not presented for parsimony.

${ }^{+} p<.1 ;{ }^{*} p<.05 ;{ }^{* *} p<.01 ;{ }^{* * *} p<.001$

that adolescents falling in the lowest quintile of family wealth tended to exhibit higher levels of internalizing problems than children in wealthier families (ranging from 0.11 to 0.23 SD). Unlike in early childhood, adolescents in the first and second wealth showed significantly different levels of internalizing, with children in the lowest quintile exhibiting 0.11 SD more internalizing problems than those in the second quintile on average.
Associations Between Income Level, Income Volatility, and Child Development Next, we tested whether links between child outcomes and both income volatility and income level vary according to level of wealth. Overall, the evidence suggested that family wealth buffers children's development from low levels of family income across all developmental stages. However, wealth did not moderate links between achievement and volatility. 
Table 4. Main Effects and Interactions for Income Dynamics and Categorical Wealth for Internalizing

\begin{tabular}{|c|c|c|c|c|c|c|}
\hline \multirow[b]{3}{*}{ Predictors } & \multicolumn{6}{|c|}{ Internalizing } \\
\hline & \multicolumn{2}{|c|}{ Early Childhood } & \multicolumn{2}{|c|}{ Middle Childhood } & \multicolumn{2}{|c|}{ Adolescence } \\
\hline & Coef. & SE & Coef. & SE & Coef. & SE \\
\hline \multicolumn{7}{|l|}{ Main effects } \\
\hline Income & $-0.04^{* * *}$ & $(0.01)$ & $-0.04^{* * *}$ & $(0.01)$ & $-0.05^{* * *}$ & (0.01) \\
\hline Income shocks & 0.02 & $(0.03)$ & $0.04^{*}$ & $(0.02)$ & $0.05^{* *}$ & $(0.02)$ \\
\hline Wealth: second quantile & $-0.00 \mathrm{abc}$ & $(0.04)$ & $-0.09 * a b c$ & $(0.04)$ & $-0.11^{* * a b}$ & $(0.04)$ \\
\hline Wealth: third quantile & $-0.10 * a$ & $(0.04)$ & $-0.18^{* * * \text { ade }}$ & $(0.04)$ & $-0.16^{* * *}$ & $(0.04)$ \\
\hline Wealth: fourth quantile & $-0.15^{* * * b}$ & $(0.05)$ & $-0.26^{* * * \text { bd }}$ & $(0.05)$ & $-0.21^{* * * a}$ & (0.05) \\
\hline Wealth: fifth quantile & $-0.16^{* *_{c}}$ & $(0.05)$ & $-0.29^{* * * \mathrm{ce}}$ & $(0.05)$ & $-0.23^{* * * b}$ & $(0.05)$ \\
\hline Constant & $1.12^{* * *}$ & $(0.24)$ & $1.63^{* * *}$ & $(0.24)$ & $1.61^{* * *}$ & $(0.26)$ \\
\hline \multicolumn{7}{|l|}{$\begin{array}{l}\text { Wealth interactions } \\
\text { with income }\end{array}$} \\
\hline Income & $-0.05^{* * *}$ & $(0.01)$ & $-0.04^{* * *}$ & $(0.01)$ & $-0.05^{* * *}$ & (0.01) \\
\hline Income shocks & 0.02 & $(0.03)$ & $0.04^{*}$ & $(0.02)$ & $0.05^{* *}$ & $(0.02)$ \\
\hline Wealth: second quantile & $-0.08^{a}$ & $(0.10)$ & $-0.23^{+}$ & $(0.13)$ & -0.23 & $(0.16)$ \\
\hline Wealth: third quantile & -0.20 & $(0.17)$ & -0.17 & $(0.20)$ & 0.02 & $(0.26)$ \\
\hline Wealth: fourth quantile & -0.18 & $(0.24)$ & -0.15 & $(0.32)$ & -0.02 & $(0.40)$ \\
\hline Wealth: fifth quantile & $-0.66^{* * b}$ & $(0.25)$ & $-0.72^{*}$ & $(0.34)$ & $-0.65^{+}$ & (0.37) \\
\hline Income*second quantile & 0.01 & $(0.01)$ & 0.02 & $(0.02)$ & 0.01 & $(0.02)$ \\
\hline Income*third quantile & 0.01 & $(0.02)$ & 0.00 & $(0.02)$ & -0.02 & (0.03) \\
\hline Income*fourth quantile & 0.01 & $(0.02)$ & -0.01 & $(0.03)$ & -0.02 & (0.04) \\
\hline Income*fifth quantile & $0.05^{*}$ & $(0.02)$ & 0.04 & (0.03) & 0.04 & (0.03) \\
\hline Constant & $1.14^{* * *}$ & $(0.24)$ & $1.65^{* * *}$ & $(0.24)$ & $1.62^{* * *}$ & $(0.27)$ \\
\hline \multirow{2}{*}{\multicolumn{7}{|c|}{$\begin{array}{l}\text { Wealth interactions with } \\
\text { income shocks }\end{array}$}} \\
\hline & & & & & & \\
\hline Income & $-0.04^{* * *}$ & $(0.01)$ & $-0.04^{* * *}$ & $(0.01)$ & $-0.05^{* * *}$ & $(0.01)$ \\
\hline Income shocks & 0.04 & $(0.06)$ & 0.01 & $(0.04)$ & $0.08^{*}$ & (0.04) \\
\hline Wealth: second quantile & -0.04 & $(0.06)$ & $-0.11^{\mathrm{ab}}$ & $(0.07)$ & -0.09 & (0.08) \\
\hline Wealth: third quantile & -0.06 & $(0.06)$ & $-0.25^{* * *}$ & $(0.07)$ & -0.08 & (0.09) \\
\hline Wealth: fourth quantile & $-0.12^{+}$ & $(0.06)$ & $-0.27^{* * * a}$ & $(0.07)$ & -0.14 & (0.09) \\
\hline Wealth: fifth quantile & $-0.12^{+}$ & $(0.07)$ & $-0.35^{* * * b}$ & $(0.08)$ & $-0.20^{*}$ & (0.09) \\
\hline Income shockssecond quantile & 0.06 & $(0.08)$ & 0.02 & $(0.06)$ & -0.02 & $(0.05)$ \\
\hline Income shocks*third quantile & -0.06 & $(0.08)$ & 0.07 & $(0.06)$ & -0.06 & (0.05) \\
\hline Income shocks*fourth quantile & -0.04 & $(0.08)$ & 0.01 & $(0.06)$ & -0.05 & (0.05) \\
\hline Income shocks*fifth quantile & -0.06 & $(0.08)$ & 0.07 & $(0.06)$ & -0.02 & $(0.06)$ \\
\hline Constant & $1.10^{* * *}$ & $(0.24)$ & $1.64^{* * *}$ & $(0.24)$ & $1.59^{* * *}$ & $(0.27)$ \\
\hline
\end{tabular}

Source: Authors' calculations from the NLSY.

Note: $\mathrm{N}=8,095$. Standard errors in parentheses. Wealth quintiles are compared to the first quintile.

Post hoc analyses tested the significance of differences between other wealth quintiles. Within each column, coefficients with shared superscript letters are different from each other at the $p<.05$ level. Child (cohort, gender, and race), mother (marital status, AFQT, education, employment status, and age at birth of first child), and household (number of children at home and urbanicity) characteristics were included in the model but not presented for parsimony.

${ }^{+} p<.1 ;{ }^{*} p<.05 ;{ }^{* *} p<.01 ;{ }^{* * *} p<.001$ 
Table 5. Adolescent Outcomes Predicted by Family Economic Characteristics

\begin{tabular}{|c|c|c|c|c|}
\hline Predictors & $\begin{array}{l}\text { Internalizing } \\
\text { Coef. } \\
\text { (SE) }\end{array}$ & $\begin{array}{c}\text { Externalizing } \\
\text { Coef. } \\
\text { (SE) }\end{array}$ & $\begin{array}{l}\text { Math } \\
\text { Coef. } \\
\text { (SE) }\end{array}$ & $\begin{array}{l}\text { Reading } \\
\text { Coef. } \\
\text { (SE) }\end{array}$ \\
\hline Income & $\begin{array}{l}-0.06^{* * *} \\
(0.01)\end{array}$ & $\begin{array}{l}-0.05^{* * *} \\
(0.01)\end{array}$ & $\begin{array}{l}0.02^{* * *} \\
(0.01)\end{array}$ & $\begin{array}{l}0.04^{* * *} \\
(0.01)\end{array}$ \\
\hline Income shock & $\begin{array}{l}0.05^{* *} \\
(0.02)\end{array}$ & $\begin{array}{l}0.06^{* * *} \\
(0.02)\end{array}$ & $\begin{array}{c}-0.03^{+} \\
(0.01)\end{array}$ & $\begin{array}{c}-0.00 \\
(0.01)\end{array}$ \\
\hline Wealth & $\begin{array}{c}-0.11^{+} \\
(0.06)\end{array}$ & $\begin{array}{c}-0.18^{* *} \\
(0.06)\end{array}$ & $\begin{array}{l}0.29^{* * *} \\
(0.06)\end{array}$ & $\begin{array}{l}0.21^{* * *} \\
(0.06)\end{array}$ \\
\hline Black & $\begin{array}{c}-0.13^{*} \\
(0.05)\end{array}$ & $\begin{array}{c}-0.02 \\
(0.04)\end{array}$ & $\begin{array}{c}-0.13^{* *} \\
(0.04)\end{array}$ & $\begin{array}{c}-0.28^{* * *} \\
(0.03)\end{array}$ \\
\hline Other & $\begin{array}{c}0.05 \\
(0.04)\end{array}$ & $\begin{array}{l}0.14^{* *} \\
(0.04)\end{array}$ & $\begin{array}{l}0.13^{* * *} \\
(0.04)\end{array}$ & $\begin{array}{c}-0.05^{+} \\
(0.03)\end{array}$ \\
\hline Marital status & $\begin{array}{c}-0.07^{+} \\
(0.04)\end{array}$ & $\begin{array}{l}-0.23^{* * *} \\
(0.04)\end{array}$ & $\begin{array}{l}0.10^{* *} \\
(0.04)\end{array}$ & $\begin{array}{l}0.15^{* * *} \\
(0.03)\end{array}$ \\
\hline AFQT & $\begin{array}{c}0.01 \\
(0.02)\end{array}$ & $\begin{array}{c}0.03 \\
(0.02)\end{array}$ & $\begin{array}{l}0.27^{* * *} \\
(0.02)\end{array}$ & $\begin{array}{l}0.28^{* * *} \\
(0.02)\end{array}$ \\
\hline Female & $\begin{array}{c}-0.03 \\
(0.03)\end{array}$ & $\begin{array}{l}-0.16^{* * *} \\
(0.03)\end{array}$ & $\begin{array}{c}-0.07^{* *} \\
(0.02)\end{array}$ & $\begin{array}{l}0.11^{* * *} \\
(0.02)\end{array}$ \\
\hline Mother's education & $\begin{array}{l}-0.10^{* *} \\
(0.03)\end{array}$ & $\begin{array}{c}-0.06 \\
(0.04)\end{array}$ & $\begin{array}{c}0.03 \\
(0.03)\end{array}$ & $\begin{array}{c}0.07^{*} \\
(0.03)\end{array}$ \\
\hline Mother's education squared & $\begin{array}{l}0.00^{* *} \\
(0.00)\end{array}$ & $\begin{array}{c}0.00 \\
(0.00)\end{array}$ & $\begin{array}{c}-0.00 \\
(0.00)\end{array}$ & $\begin{array}{c}-0.00 \\
(0.00)\end{array}$ \\
\hline Mother's employment & $\begin{array}{c}-0.24^{* *} \\
(0.08)\end{array}$ & $\begin{array}{l}-0.39^{* * *} \\
(0.08)\end{array}$ & $\begin{array}{c}-0.01 \\
(0.06)\end{array}$ & $\begin{array}{c}0.07 \\
(0.06)\end{array}$ \\
\hline Number of children & $\begin{array}{c}-0.04^{* *} \\
(0.01)\end{array}$ & $\begin{array}{c}-0.03^{*} \\
(0.02)\end{array}$ & $\begin{array}{l}-0.04^{* * *} \\
(0.01)\end{array}$ & $\begin{array}{c}-0.11^{* * *} \\
(0.01)\end{array}$ \\
\hline Urbanicity & $\begin{array}{c}-0.00 \\
(0.04)\end{array}$ & $\begin{array}{c}-0.00 \\
(0.04)\end{array}$ & $\begin{array}{c}0.00 \\
(0.03)\end{array}$ & $\begin{array}{c}0.01 \\
(0.03)\end{array}$ \\
\hline Mother's age at birth & $\begin{array}{l}-0.00 \\
(0.00)\end{array}$ & $\begin{array}{c}-0.00 \\
(0.00)\end{array}$ & $\begin{array}{c}0.00 \\
(0.00)\end{array}$ & $\begin{array}{c}-0.00 \\
(0.00)\end{array}$ \\
\hline Constant & $\begin{array}{l}3.025^{* * *} \\
(0.739)\end{array}$ & $\begin{array}{l}4.05^{* * *} \\
(0.83)\end{array}$ & $\begin{array}{l}-4.34^{* * *} \\
(0.75)\end{array}$ & $\begin{array}{c}-3.67^{* * *} \\
(0.75)\end{array}$ \\
\hline
\end{tabular}

Source: Authors' calculations from the NLSY.

Note: $\mathrm{N}=8,095$. Standard errors in parentheses. Child cohort was included in the model but not presented for parsimony.

${ }^{+} p<.1 ;{ }^{*} p<.05 ;{ }^{* *} p<.01 ;{ }^{* * *} p<.001$

Table 6 presents the results of models testing interactions between wealth and income predicting early childhood development. Only two interactions were significant. Wealth buffered the effects of volatility on early childhood externalizing problems (table 6, panel B). As wealth increased, positive links between volatility and externalizing diminished. Wealth also buffered the effects of income level on early childhood behavior problems. Specifically, as wealth increased, negative links between annual income and internalizing grew smaller (table 6, panel A).

Wealth attenuated links between income level and child outcomes in middle childhood (table 7, panel A). As wealth increased, the negative associations between annual income and internalizing and externalizing behaviors and the positive relations between annual income and math achievement grew smaller. Finally, 
Table 6. Results of Interactions Between Wealth and Income Dynamics for Early Childhood

\begin{tabular}{|c|c|c|c|c|}
\hline Predictors & $\begin{array}{l}\text { Internalizing } \\
\text { Coef. } \\
\text { (SE) }\end{array}$ & $\begin{array}{l}\text { Externalizing } \\
\text { Coef. } \\
\text { (SE) }\end{array}$ & $\begin{array}{l}\text { Math } \\
\text { Coef. } \\
\text { (SE) }\end{array}$ & $\begin{array}{l}\text { Reading } \\
\text { Coef. } \\
\text { (SE) }\end{array}$ \\
\hline \multicolumn{5}{|c|}{$\begin{array}{l}\text { Panel A. Wealth interactions } \\
\text { with income }\end{array}$} \\
\hline Income & $\begin{array}{l}-1.35^{* *} \\
(0.49)\end{array}$ & $\begin{array}{l}-0.95 \\
(0.69)\end{array}$ & $\begin{array}{c}0.31 \\
(0.41)\end{array}$ & $\begin{array}{c}0.15 \\
(0.40)\end{array}$ \\
\hline Income shocks & $\begin{array}{c}0.03 \\
(0.03)\end{array}$ & $\begin{array}{r}0.06^{*} \\
(0.03)\end{array}$ & $\begin{array}{l}-0.09^{* * *} \\
(0.03)\end{array}$ & $\begin{array}{r}-0.07^{*} \\
(0.03)\end{array}$ \\
\hline Wealth & $\begin{array}{l}-1.24^{* *} \\
(0.44)\end{array}$ & $\begin{array}{r}-1.08^{+} \\
(0.62)\end{array}$ & $\begin{array}{c}0.44 \\
(0.37)\end{array}$ & $\begin{array}{c}0.31 \\
(0.35)\end{array}$ \\
\hline Wealth*income & $\begin{array}{l}0.10^{* *} \\
(0.04)\end{array}$ & $\begin{array}{c}0.07 \\
(0.06)\end{array}$ & $\begin{array}{l}-0.02 \\
(0.03)\end{array}$ & $\begin{array}{c}-0.01 \\
(0.03)\end{array}$ \\
\hline Constant & $\begin{array}{c}16.74^{* *} \\
(5.52)\end{array}$ & $\begin{array}{c}15.41^{*} \\
(7.76)\end{array}$ & $\begin{array}{c}-6.51 \\
(4.59)\end{array}$ & $\begin{array}{l}-5.05 \\
(4.41)\end{array}$ \\
\hline \multicolumn{5}{|c|}{$\begin{array}{l}\text { Panel B. Wealth interactions } \\
\text { with volatility }\end{array}$} \\
\hline Income & $\begin{array}{l}-0.04^{* * *} \\
(0.01)\end{array}$ & $\begin{array}{l}-0.03^{* * *} \\
(0.01)\end{array}$ & $\begin{array}{l}0.02^{* * *} \\
(0.01)\end{array}$ & $\begin{array}{l}0.02^{*} \\
(0.01)\end{array}$ \\
\hline Income shocks & $\begin{array}{c}1.78 \\
(1.35)\end{array}$ & $\begin{array}{c}3.12^{*} \\
(1.25)\end{array}$ & $\begin{array}{c}1.16 \\
(1.26)\end{array}$ & $\begin{array}{l}-1.21 \\
(1.60)\end{array}$ \\
\hline Wealth & $\begin{array}{l}-0.02 \\
(0.08)\end{array}$ & $\begin{array}{l}-0.14^{+} \\
(0.08)\end{array}$ & $\begin{array}{l}0.24^{* *} \\
(0.08)\end{array}$ & $\begin{array}{c}0.15 \\
(0.09)\end{array}$ \\
\hline Wealthincome shock & $\begin{array}{l}-0.14 \\
(0.11)\end{array}$ & $\begin{array}{l}-0.24^{*} \\
(0.10)\end{array}$ & $\begin{array}{l}-0.10 \\
(0.10)\end{array}$ & $\begin{array}{c}0.09 \\
(0.13)\end{array}$ \\
\hline Constant & $\begin{array}{c}1.48 \\
(1.07)\end{array}$ & $\begin{array}{l}3.70^{* * *} \\
(1.03)\end{array}$ & $\begin{array}{l}-4.00^{* * *} \\
(1.01)\end{array}$ & $\begin{array}{l}-2.98^{* *} \\
(1.11)\end{array}$ \\
\hline
\end{tabular}

Source: Authors' calculations from the NLSY.

Note: $\mathrm{N}=8,095$. Standard errors in parentheses. Child (cohort, gender, and race), mother (marital status, AFQT, education, employment status, and age at birth of first child), and household (number of children at home and urbanicity) characteristics were included in the model but not presented for parsimony.

${ }^{+} p<.1 ;{ }^{*} p<.05 ;{ }^{* *} p<.01 ;{ }^{* * *} p<.001$

wealth buffered the effects of income level on adolescent behavior problems and achievement (table 8, panel A). Specifically, increases in wealth buffered the negative associations between annual income and externalizing behaviors and the positive relations between annual income and math and reading achievement.

\section{DISCUSSION}

Using data from a nationally representative cohort of families and children, this study examines how wealth relates to child achievement and behavior, controlling for other aspects of family economic conditions. It adds to the wealth literature by using detailed information on wealth measured from before the child's birth through adolescence. Moreover, it documents associations during three distinct developmental periods: early childhood, middle childhood, and adolescence. Last, this study is one of the first to explore whether wealth acts as a buffer for children experiencing low levels of income or high income volatility.

Results showed three general patterns. First, more wealth was related to better achievement and fewer behavioral problems at all developmental stages. Next, contrary to our hypotheses, wealth associations were quite stable over 
Table 7. Results of Interactions Between Wealth and Income Dynamics for Middle Childhood

\begin{tabular}{|c|c|c|c|c|}
\hline Predictors & $\begin{array}{l}\text { Internalizing } \\
\text { Coef. } \\
\text { (SE) }\end{array}$ & $\begin{array}{l}\text { Externalizing } \\
\text { Coef. } \\
\text { (SE) }\end{array}$ & $\begin{array}{l}\text { Math } \\
\text { Coef. } \\
\text { (SE) }\end{array}$ & $\begin{array}{l}\text { Reading } \\
\text { Coef. } \\
\text { (SE) }\end{array}$ \\
\hline \multicolumn{5}{|c|}{$\begin{array}{l}\text { Panel A. Wealth interactions } \\
\text { with income }\end{array}$} \\
\hline Income & $\begin{array}{c}-1.51^{*} \\
(0.62)\end{array}$ & $\begin{array}{r}-1.15^{+} \\
(0.60)\end{array}$ & $\begin{array}{l}1.55^{* *} \\
(0.49)\end{array}$ & $\begin{array}{l}0.81^{+} \\
(0.46)\end{array}$ \\
\hline Income shocks & $\begin{array}{r}0.04^{*} \\
(0.02)\end{array}$ & $\begin{array}{c}0.01 \\
(0.02)\end{array}$ & $\begin{array}{l}-0.01 \\
(0.02)\end{array}$ & $\begin{array}{l}-0.01 \\
(0.02)\end{array}$ \\
\hline Wealth & $\begin{array}{l}-1.47^{* *} \\
(0.56)\end{array}$ & $\begin{array}{c}-1.19^{*} \\
(0.54)\end{array}$ & $\begin{array}{l}1.57^{* * *} \\
(0.44)\end{array}$ & $\begin{array}{l}0.85^{*} \\
(0.41)\end{array}$ \\
\hline Wealth*income & $\begin{array}{l}0.12^{*} \\
(0.05)\end{array}$ & $\begin{array}{r}0.09^{+} \\
(0.05)\end{array}$ & $\begin{array}{l}-0.12^{* *} \\
(0.04)\end{array}$ & $\begin{array}{r}-0.06^{+} \\
(0.04)\end{array}$ \\
\hline Constant & $\begin{array}{l}20.21^{* *} \\
(6.93)\end{array}$ & $\begin{array}{r}17.06^{*} \\
(6.75)\end{array}$ & $\begin{array}{c}-20.25^{* * *} \\
(5.55)\end{array}$ & $\begin{array}{r}-11.53^{*} \\
(5.16)\end{array}$ \\
\hline \multicolumn{5}{|c|}{$\begin{array}{l}\text { Panel B. Wealth interactions } \\
\text { with volatility }\end{array}$} \\
\hline Income & $\begin{array}{l}-0.05^{* * *} \\
(0.01)\end{array}$ & $\begin{array}{l}-0.03^{* * *} \\
(0.01)\end{array}$ & $\begin{array}{l}0.03^{* * *} \\
(0.01)\end{array}$ & $\begin{array}{l}0.03^{* * *} \\
(0.01)\end{array}$ \\
\hline Income shocks & $\begin{array}{l}-0.38 \\
(0.85)\end{array}$ & $\begin{array}{l}-0.38 \\
(0.86)\end{array}$ & $\begin{array}{c}0.93 \\
(0.79)\end{array}$ & $\begin{array}{l}0.05 \\
(0.84)\end{array}$ \\
\hline Wealth & $\begin{array}{l}-0.21^{*} \\
(0.09)\end{array}$ & $\begin{array}{l}-0.22^{*} \\
(0.10)\end{array}$ & $\begin{array}{l}0.30^{* * *} \\
(0.08)\end{array}$ & $\begin{array}{l}0.16^{+} \\
(0.09)\end{array}$ \\
\hline Wealth*income shocks & $\begin{array}{c}0.03 \\
(0.07)\end{array}$ & $\begin{array}{l}0.03 \\
(0.07)\end{array}$ & $\begin{array}{l}-0.07 \\
(0.06)\end{array}$ & $\begin{array}{l}-0.00 \\
(0.07)\end{array}$ \\
\hline Constant & $\begin{array}{l}4.41^{* * *} \\
(1.12)\end{array}$ & $\begin{array}{l}4.98^{* * *} \\
(1.26)\end{array}$ & $\begin{array}{l}-4.33^{* * *} \\
(1.04)\end{array}$ & $\begin{array}{l}-2.90^{* *} \\
(1.12)\end{array}$ \\
\hline
\end{tabular}

Source: Authors' calculations from the NLSY.

Note: $\mathrm{N}=8,095$. Standard errors in parentheses. Child (cohort, gender, and race), mother (marital status, AFQT, education, employment status, and age at birth of first child), and household (number of children at home and urbanicity) characteristics were included in the model but not presented for parsimony.

${ }^{+} p<.1 ;{ }^{*} p<.05 ;{ }^{* *} p<.01 ;{ }^{* * *} p<.001$

child age. Finally, evidence suggests that links between income level, but not volatility, and child functioning vary by level of family wealth. Taken together, the results provide a better understanding of the role wealth and income dynamics play-separately and jointly-in the academic and behavioral development across childhood.

\section{Associations Across Domains and Development}

This study provides new evidence of wealth's association with both academic and behavioral functioning at three developmental stages.
Controlling for both income level and volatility, as well as for a multitude of other characteristics of parents and children, wealth consistently predicted reading and math achievement as well as externalizing problems. Alternate model specifications showed links between wealth and internalizing across development as well. These links were apparent when comparing children in low-wealth households to very wealthy children, but almost no differences were observed when comparing midwealth children with their wealthier peers. To put these associations into perspective, hypothetically considering low-income families 
Table 8. Results of Interactions Between Wealth and Income Dynamics for Adolescence

\begin{tabular}{|c|c|c|c|c|}
\hline Predictors & $\begin{array}{l}\text { Internalizing } \\
\text { Coef. } \\
\text { (SE) }\end{array}$ & $\begin{array}{l}\text { Externalizing } \\
\text { Coef. } \\
\text { (SE) }\end{array}$ & $\begin{array}{l}\text { Math } \\
\text { Coef. } \\
\text { (SE) }\end{array}$ & $\begin{array}{c}\text { Reading } \\
\text { Coef. } \\
\text { (SE) }\end{array}$ \\
\hline \multicolumn{5}{|c|}{$\begin{array}{l}\text { Panel A. Wealth interactions } \\
\text { with income }\end{array}$} \\
\hline Income & $\begin{array}{r}-1.42^{+} \\
(0.73)\end{array}$ & $\begin{array}{c}-1.71^{*} \\
(0.70)\end{array}$ & $\begin{array}{l}1.83^{* * *} \\
(0.44)\end{array}$ & $\begin{array}{l}2.06^{* * *} \\
(0.50)\end{array}$ \\
\hline Income shocks & $\begin{array}{l}0.05^{* *} \\
(0.02)\end{array}$ & $\begin{array}{l}0.06^{* * *} \\
(0.02)\end{array}$ & $\begin{array}{l}-0.03^{*} \\
(0.01)\end{array}$ & $\begin{array}{l}-0.01 \\
(0.01)\end{array}$ \\
\hline Wealth & $\begin{array}{l}-1.31^{*} \\
(0.66)\end{array}$ & $\begin{array}{l}-1.65^{* *} \\
(0.62)\end{array}$ & $\begin{array}{l}1.89^{* * *} \\
(0.39)\end{array}$ & $\begin{array}{l}2.00^{* * *} \\
(0.46)\end{array}$ \\
\hline Wealth*income & $\begin{array}{c}0.11^{+} \\
(0.06)\end{array}$ & $\begin{array}{r}0.13^{*} \\
(0.06)\end{array}$ & $\begin{array}{l}-0.14^{* * *} \\
(0.03)\end{array}$ & $\begin{array}{l}-0.16^{* * *} \\
(0.04)\end{array}$ \\
\hline Constant & $\begin{array}{c}18.11^{*} \\
(8.27)\end{array}$ & $\begin{array}{l}22.46^{* *} \\
(7.77)\end{array}$ & $\begin{array}{c}-24.35^{\star * *} \\
(4.95)\end{array}$ & $\begin{array}{c}-26.04^{* * *} \\
(5.80)\end{array}$ \\
\hline \multicolumn{5}{|c|}{$\begin{array}{l}\text { Panel B. Wealth interactions } \\
\text { with volatility }\end{array}$} \\
\hline Income & $\begin{array}{l}-0.06^{* * *} \\
(0.01)\end{array}$ & $\begin{array}{l}-0.05^{* * *} \\
(0.01)\end{array}$ & $\begin{array}{l}0.02^{* * *} \\
(0.01)\end{array}$ & $\begin{array}{l}0.04^{* * *} \\
(0.01)\end{array}$ \\
\hline Income shocks & $\begin{array}{l}0.47 \\
(0.75)\end{array}$ & $\begin{array}{l}-0.51 \\
(0.67)\end{array}$ & $\begin{array}{l}0.55 \\
(0.57)\end{array}$ & $\begin{array}{c}0.82 \\
(0.63)\end{array}$ \\
\hline Wealth & $\begin{array}{l}-0.06 \\
(0.09)\end{array}$ & $\begin{array}{l}-0.23^{* *} \\
(0.09)\end{array}$ & $\begin{array}{l}0.35^{* * *} \\
(0.09)\end{array}$ & $\begin{array}{l}0.29^{* * *} \\
(0.08)\end{array}$ \\
\hline Wealth*income shocks & $\begin{array}{l}-0.03 \\
(0.06)\end{array}$ & $\begin{array}{l}0.05 \\
(0.05)\end{array}$ & $\begin{array}{l}-0.05 \\
(0.05)\end{array}$ & $\begin{array}{l}-0.07 \\
(0.05)\end{array}$ \\
\hline Constant & $\begin{array}{c}2.50^{*} \\
(1.22)\end{array}$ & $\begin{array}{l}4.77^{* * *} \\
(1.18)\end{array}$ & $\begin{array}{l}-5.06^{* * *} \\
(1.11)\end{array}$ & $\begin{array}{l}-4.71^{* * *} \\
(1.05)\end{array}$ \\
\hline
\end{tabular}

Source: Authors' calculations from the NLSY.

Note: $\mathrm{N}=8,095$. Standard errors in parentheses. Child (cohort, gender, and race), mother (marital status, AFQT, education, employment status, and age at birth of first child), and household (number of children at home and urbanicity) characteristics were included in the model but not presented for parsimony.

${ }^{+} p<.1 ;{ }^{*} p<.05 ;{ }^{* *} p<.01 ;{ }^{* * *} p<.001$

with $\$ 1,000$ in assets, holding everything else constant, our results suggest that saving a little more than $\$ 1,000$ per year for five years would reduce income disparities in achievement by 40 percent and almost entirely close the socioeconomic status (SES)-behavioral gap. Or, to present another hypothetical, our results suggest decreasing the family's credit card debt from the U.S. average (about $\$ 6,000$ ) to $\$ 1,000$ would close income gaps in achievement and behavior by the same magnitude. Indeed, the wealth-child outcome associations observed in this study are much larger than the incomechild outcome associations. We conducted post hoc analyses to compare the size of wealth and income coefficients to determine whether the wealth associations were significantly larger than income associations. These post hoc tests showed that in all cases where wealth is a significant predictor of achievement or behaviors, it has a stronger relation to child development than family income does. Specifically, a log unit change in wealth was linked to changes in achievement and behavior that ranged from about five to ten times larger than a similar change in family income. These findings suggest that programs and policies aimed at increasing family net worth, such as child 
development accounts or debt reduction interventions, may do more to reduce SES disparities in children's academic and behavioral skills than efforts focused on increasing income alone.

This study contributes to the wealth literature in other ways as well. First, it extends the wealth literature by looking at behavioral outcomes. Given that much of the literature on wealth has focused on its implications for childhood and adult academic outcomes and, to a lesser extent, other human capital outcomes, this is an important advancement. Because we observe associations between wealth and behavior in childhood, it will be interesting to explore whether this association extends into adulthood in future studies. Second, this is the first study to document these associations across early childhood, middle childhood, and adolescence. Exploring these relations longitudinally, we were able to see that links between wealth and child outcomes remain fairly stable with age. This is inconsistent with our hypotheses and theory (Orr 2003; Yeung and Conley 2008). It is also inconsistent with work featured in this issue that showed debt, specifically child support arrears, had stronger links to child behavior problems at fifteen years old than at nine years old (Nepomnyaschy et al. 2021, this issue). This points to an important future direction for wealth research. More studies are needed that break net worth into its numerous components, like assets and debts, liquid and nonliquid assets, good debt and bad debt, or secured and unsecured debt, to get a better picture of how subcomponents of wealth relate to different aspects of child development at various ages (Conwell and Ye 2021, this issue; Nepomnyaschy et al. 2021, this issue). Also, because adolescence marks the time when children begin to understand their socioeconomic position relative to others and internalize stereotypes regarding wealthier and less wealthy families, it may be important to include information on adolescents' subjective financial well-being (Gibson-Davis and Hill 2021, this issue). Adolescents' subjective financial wellbeing factors into their emotions and attitudes, including feelings of depression or anxiety about their social standing or attitudes about the importance of schoolwork for their future educational or career prospects (Shim et al. 2009). These emotions and attitudes may have a direct impact on both achievement and behavioral functioning (Shim et al. 2009). Unfortunately, the NLSY does not include a measure of adolescents' feelings of financial stress or well-being, which may be important missing information that, when accounted for, could explain associations between wealth and adolescent outcomes. Indeed, our lab is currently conducting a study that collects measures of adolescents' perceptions of financial strain and well-being, as well as measures of achievement and behavior problems and family income and wealth, in an effort to examine how these perceptions explain or alter the roles of income and wealth in their development.

As with prior studies, links between wealth and math skills were slightly stronger than wealth's links to reading achievement. This finding remains unexplained and calls for additional research exploring its etiology. Indeed, the mechanisms explaining wealth's associations with child development is an understudied area. It will be important for future research to examine more carefully the family processes, including parental investments and stress, that underlie links between wealth and children's achievement and behavior. Moderating factors may be important to consider when looking at wealth effects on child development as well. As articles in this issue highlight (Conwell and Ye 2021, this issue; Gibson-Davis and Hill 2021, this issue), racial disparities in wealth accumulation and debt avoidance are pronounced. But race may also moderate links between wealth and child outcomes. For instance, increased wealth may not confer the same or similar benefits to black families as to white families if, as research suggests, it does not buy black families the same entrée into social and cultural capital due to racial biases. When black families accrue greater wealth, it does not translate into increased social and cultural capital to the same extent as white families because of historic patterns of racism and discrimination (Conley 2010; Henry, Votruba-Drzal, and Miller 2019). Moreover, structural and historical discrimination may place black families, even when wealthy, in close proximity to spatial, relational, and intergenerational disadvantage 
that may limit the extent to which wealth can be leveraged for investments in children's development (Henry, Votruba-Drzal, and Miller 2019). In this case, we would expect links between wealth and child outcomes to be weaker for black families. Other potential buffers from low levels of wealth that should be explored in future work include grandparent wealth and parental education, given that these factors may both give families social status and entrée to social and cultural capital attendant with high wealth (Gibson-Davis and Hill 2021, this issue), in which case, links between wealth and child development would be attenuated for children with wealthier grandparents or highly educated parents.

\section{Wealth May Buffer Children in Low-Income Families}

Another novel finding from this study is that wealth may buffer children against the negative academic and behavioral implications of low family income. It is important to acknowledge, however, that the protective role of family wealth tended to be selective and was not consistently present for all outcomes at every developmental stage. In particular, the importance of wealth as a buffer from low levels of income appeared to grow as children age. Wealth moderation was minimal in early childhood, but present for both academic and behavioral outcomes in middle childhood and adolescence.

These findings are consistent with our hypotheses and research on the role of wealth in stabilizing family finances (Rauscher and Elliott 2016). The extent to which families leverage wealth to stabilize family income or provide an influx of money or that families have less debt may help stave off stress accompanying periods of low income or increase the money available to meet financial obligations or make promotive investments in children. Interestingly, although our hypotheses regarding the growing importance of family wealth as youth age were not supported by the results of main effects of wealth, we do see in the moderation analyses that the buffering role of wealth does indeed grow as children get older. This perhaps suggests that as children approach adolescence, the status and cultural capital that comes with high levels of wealth can protect children from the harmful effects of low levels of income in ways that it cannot when children are in early childhood and less aware of their social standing (Orr 2003; Yeung and Conley 2008). Visible forms of wealth like driving the "right car," living in a "good neighborhood" in a "nice house" or attending a "good school" may give older children a sense of relative class privilege, confidence, and security. Young children are less likely to pick up on these status symbols. Regardless of income, wealth may give families access to the social and cultural capital enabling them to connect their children to social networks that put children on trajectories of academic success and guide them away from maladaptive behaviors that manifest during late childhood and early adolescence. Thus, even in times of economic hardship or low income, wealth could serve as a guarantee that these youth are exposed to learning opportunities and experiences that promote high achievement and opportunities for relationships and interactions that promote positive social and emotional development. Additionally, wealth may relate to parent and teacher expectations of academic success, all of which become more important as children age.

Surprisingly, the buffering role of wealth did not extend to income volatility. In fact, our findings related to the role of income volatility in predicting child outcomes were generally weaker in all analyses. This may be due to the volatility measure used in this study. Given the sampling time frame of the NLSY, our volatility measure represented changes in income over two years. However, the impact of income volatility on families and children may be driven more by variability in income earned week to week or month to month more so than biyearly income changes (Hill et al. 2013). The NLSY does not include data on families' earnings at shorter intervals, but we are currently engaged in a study that collects monthly reports of families' income, as well as a host of other measures, which will allow us to create month-tomonth measures of income volatility and test how they relate to child and family functioning. Future work would be wise to test whether volatility in family wealth has implications for 
children's development-a question that has yet to be addressed in the literature.

\section{Limitations}

First, these results are correlational and therefore must be interpreted cautiously. Family income dynamics and wealth are not randomly assigned. Instead, parents make choices that affect their earnings and wealth, and the characteristics influencing their selections regarding economic factors also shape the proximal contexts in which their children develop. To reduce bias, we included covariates for factors such as marital status and employment in our models. We also controlled for mothers' scores on the AFQT, which is widely considered a timeinvariant measure of academic aptitude related to economic conditions, parenting, and children's development (Votruba-Drzal 2006). It is still possible, however, that observed associations between wealth and child outcomes are attributable to unmeasured characteristics of parents or children.

Despite trade-offs between internal and external validity, both are important in developmental studies (Miller, Henry, and VotrubaDrzal 2016). Studies using experimental or quasi-experimental designs often use samples that represent a small, unique population (see, for example, Akee et al. 2010; Conger et al. 1994; Gennetian and Miller 2002). A strength of this study is its external validity: it uses a nationally representative sample of women and their children to extend and replicate findings from the literature on family economic conditions and child development (Miller, Henry, and VotrubaDrzal 2016). Nonetheless, additional research on income and development using experimental data or quasi-experimental techniques is necessary to strengthen causal inference to inform programs and policies aimed at eliminating economic disparities in child outcomes (Miller, Henry, and Votruba-Drzal 2016).

\section{CONCLUSION}

Using representative data, this study provides useful information regarding the role of wealth in childhood academic and behavioral disparities. Throughout childhood and adolescence, wealth had independent links to child develop- ment after accounting for links between income level and volatility and development. Moreover, results suggest that wealth may buffer children from associations between low levels of income and maladaptive outcomes. Future studies to build on this research are needed to inform programs and policies aimed at narrowing economic disparities in children's life chances. Yet this work indicates that wealth is an important facet of family economic circumstances when it comes to child well-being, and it is deserving of additional research and policy attention.

\section{REFERENCES}

Akee, Randall KQ, William E. Copeland, Gordon Keeler, Adrian Angold, and E. Jane Costello. 2010. “Parents' Incomes and Children's Outcomes: A Quasi-Experiment Using Transfer Payments from Casino Profits." American Economic Journal: Applied Economics 2(1): 86-115.

Baker, Paula, C. Canada K. Keck, Frank L. Mott, Stephen V. Quinlan. 1993. NLSY Child Handbook, Revised Edition: A Guide to the 1986-1990 National Longitudinal Survey of Youth Data. Columbus: Center for Human Resource Research, Ohio State University.

Becker, Gary S. 1991. "Family Background and the Opportunities of Children." In A Treatise on the Family, by Gary S. Becker. Cambridge, Mass: Harvard University Press.

Berger, Lawrence M., and Jason N. Houle. 2016. “Parental Debt and Children's Socioemotional WellBeing." Pediatrics 137(2): e20153059.

Blair, Clancy, and Cybele Raver. 2016. "Poverty, Stress, and Brain Development: New Directions for Prevention and Intervention." Academic Pediatrics 16(3): S30-S36.

Blau, David M. 1999. "The Effect of Income on Child Development." Review of Economics and Statistics 81(2): 261-76.

Bourdieu, Pierre, and Jean-Claude Passeron. 1990. Reproduction in Education, Society and Culture. Newbury Park, Calif.: Sage Publications.

Brotman, Laurie Miller, Colleen R. O'Neal, Keng-Yen Huang, Kathleen Kiely Gouley, Amanda Rosenfelt, and Patrick E. Shrout. 2009. “An Experimental Test of Parenting Practices as a Mediator of Early Childhood Physical Aggression." Journal of Child Psychology and Psychiatry 50(3): 235-45. 
Brown, Sarah, Karl Taylor, and Stephen Wheatley Price. 2005. "Debt and Distress: Evaluating the Psychological Cost of Credit." Journal of Economic Psychology 26(5): 642-63.

Calarco, Jessica. 2014. “Coached for the Classroom: Parents' Cultural Transmission and Children's Reproduction of Educational Inequalities." American Sociological Review 79(5): 1015-37.

Center for Human Resource Research. 2002. National Longitudinal Survey of Youth 1979 Cohort, 1979-2000 (Rounds 1-19). Columbus: The Ohio State University, Bureau of Labor Statistics, and U.S. Department of Labor.

Chazan-Cohen, Rachel, Helen Raikes, Jeanne Brooks-Gunn, Catherine Ayoub, Barbara Alexander Pan, Ellen E. Kisker, Lori Roggman, and Allison Sidle Fuligni. 2009. “Low-Income Children's School Readiness: Parent Contributions over the First Five Years." Early Education and Development 20(6): 958-77.

Conger, Rand D., Xiaojia Ge, Glen H. Elder Jr., Frederick O. Lorenz, and Ronald L. Simons. 1994. “Economic Stress, Coercive Family Process, and Developmental Problems of Adolescents." Child Development 65(2): 541-61.

Conley, Dalton. 1999. Being Black, Living in the Red: Race, Wealth, and Social Policy in America. Berkeley: University of California Press.

Conley, David T. 2010. College and Career Ready: Helping All Students Succeed Beyond High School. San Francisco: Jossey-Bass.

Conwell, Jordan A., and Leafia Zi Ye. 2021. "All Wealth Is Not Created Equal: Race, Parental Net Worth, and Children's Achievement." RSF: The Russell Sage Foundation Journal of the Social Sciences 7(3): 101-21. DOI: 10.7758/RSF.2021 7.3.05.

Covay, Elizabeth, and William Carbonaro. 2010. "After the Bell: Participation in Extracurricular Activities, Classroom Behavior, and Academic Achievement." Sociology of Education 83(1): 20-45.

Diemer, Matthew A., Aixa. D. Marchand, and Rashmita S. Mistry. 2020. “Charting How Wealth Shapes Educational Pathways from Childhood to Early Adulthood: A Developmental Process Model." Journal of Youth and Adolescence 49(5): 1073-91.

Drentea, Patricia, and Paul J. Lavrakas. 2000. “Over the Limit: The Association Among Health, Race and Debt." Social Science and Medicine 50(4): 517-29.

Duncan, Greg J., Chantelle J. Dowsett, Amy Claessens, Katherine Magnuson, Aletha C. Huston, Pamela Klebanov, Linda S. Pagani, Leon Feinstein, Mimi Engel, Jeanne Brooks-Gunn, Holly Sexton, and Kathryn Duckworth. 2007. "School Readiness and Later Achievement." Developmental Psychology 43(6): 1428-46.

Duncan, Greg J., and Katherine Magnuson. 2011. "The Nature and Impact of Early Achievement Skills, Attention Skills, and Behavior Problems." In Whither Opportunity? Rising Inequality, Schools, and Children's Life Chances, edited by Greg J. Duncan and Richard J. Murnane. New York: Russell Sage Foundation.

Dunn, Lucia F., and Ida A. Mirzaie. 2016. “Consumer Debt Stress, Changes in Household Debt, and the Great Recession." Economic Inquiry 54(1): 201-14.

Easton-Brooks, Donald, and Alan Davis. 2007. "Wealth, Traditional Socioeconomic Indicators, and the Achievement Debt." Journal of Negro Education 76(4): 530-41.

Elliott, William, III, Mesmin Destin, and Terri Friedline. 2011. “Taking Stock of Ten Years of Research on the Relationship Between Assets and Children's Educational Outcomes: Implications for Theory, Policy and Intervention." Children and Youth Services Review 33(11): 2312-28.

Evans, Gary W., Carrie Gonnella, Lyscha A. Marcynyszyn, Lauren Gentile, and Nicholas Salpekar. 2005. "The Role of Chaos in Poverty and Children's Socioemotional Adjustment." Psychological Science 16(7): 560-65.

Farah, Martha J., Laura Betancourt, David M. Shera, Jessica H. Savage, Joan M. Giannetta, Nancy L. Brodsky, Elsa K. Malmud, and Hallam Hurt. 2008. "Environmental Stimulation, Parental Nurturance and Cognitive Development in Humans." Developmental Science 11(5): 793-801.

Ford, Karly Sarita, and Jason Thompson. 2016. “Inherited Prestige: Intergenerational Access to Selective Universities in the United States." Research in Social Stratification and Mobility 46(1): 86-98.

Garcia, Emma. 2015. Inequalities at the Starting Gate: Cognitive and Noncognitive Skills Gaps Between 2010-2011 Kindergarten Classmates. Washington, D.C.: Economic Policy Institute. 
Gennetian, Lisa A., and Cynthia Miller. 2002. “Children and Welfare Reform: A View from an Experimental Welfare Program in Minnesota." Child Development 73(2): 601-20.

Gershoff, Elizabeth T., J. Lawrence Aber, C. Cybele Raver, and Mary Clare Lennon. 2007. “Income Is Not Enough: Incorporating Material Hardship into Models of Income Associations with Parenting and Child Development." Child Development 78(1): 70-95.

Gibson-Davis, Christina, and Heather D. Hill. 2021. "Childhood Wealth Inequality in the United States: Implications for Social Stratification and Well-Being." RSF: The Russell Sage Foundation Journal of the Social Sciences 7(3): 1-26. DOI: 10.7758/RSF.2021.7.3.01.

Gibson-Davis, Christina M., and Christine Percheski. 2018. "Children and the Elderly: Wealth Inequality Among America's Dependents." Demography 55(3): 1009-32.

Grinstein-Weiss, Michal, Trina R. Shanks, and Sondra G. Beverly. 2014. "Family Assets and Child Outcomes: Evidence and Directions." The Future of Children 24(1): 147-70.

Hardy, Bradley. 2014. "Childhood Income Volatility and Adult Outcomes." Demography 51(5): 164165.

Heberle, Amy E., and Alice S. Carter. 2015. “Cognitive Aspects of Young Children's Experience of Economic Disadvantage." Psychological Bulletin 141(4): 723-46.

Heckman, James J. 2000. “Policies to Foster Human Capital". Research in Economics 54(1): 3-56.

Henry, Daphne A., Elizabeth Votruba-Drzal, and Portia Miller. 2019. "Child Development at the Intersection of Race and SES: An Overview." Advances in Child Development and Behavior 57:1-25.

Hill, Heather D., Pamela Morris, Lisa A. Gennetian, Sharon Wolf, and Carly Tubbs. 2013. "The Consequences of Income Instability for Children's Well-Being." Child Development Perspectives 7(2): 85-90.

Karagiannaki, Eleni. 2017. “The Effect of Parental Wealth on Children's Outcomes in Early Adulthood." Journal of Economic Inequality 15(3): 21743.

Lareau, Annette. 2015. "Cultural Knowledge and Social Inequality." American Sociological Review 80(1): 1-27.
Lê-Scherban, Félice, Allison B. Brenner, and Robert F. Schoeni. 2016. "Childhood Family Wealth and Mental Health in a National Cohort of Young Adults." SSM-Population Health 2 (December): 798-806.

Lewis, Michael, and Karen D. Rudolph. 2014. Handbook of Developmental Psychopathology. New York: Springer Science and Business Media.

Luthar, Suniya S., and Samuel H. Barkin. 2012. “Are Affluent Youth Truly 'At Risk'? Vulnerability and Resilience Across Three Diverse Samples." Development and Psychopathology 24(2): 429-49.

Magnuson, Katherine A., and Elizabeth VotrubaDrzal. 2008. “Enduring Influences of Childhood Poverty." In Changing Poverty, Changing Policies, edited by Maria Cancian and Sheldon Danziger. New York: Russell Sage Foundation.

Markwardt, Frederick C. 1997. Peabody Individual Achievement Test-Revised/Normative Update. Minneapolis, Minn.: Pearson Assessments.

Mayer, Susan. 1997. What Money Can't Buy: Family Income and Children's Life Chances. Cambridge, Mass.: Harvard University Press.

Metsäpelto, Riitta-Leena, and Lea Pulkkinen. 2012. "Socioemotional Behavior and School Achievement in Relation to Extracurricular Activity Participation in Middle Childhood." Scandinavian Journal of Educational Research 56(2): 167-82.

Miller, Portia, Laura Betancur, Kendra Whitfield, and Elizabeth Votruba-Drzal. 2020. “Examining Links Between Income and Behavior Problems Through a Developmental Psychopathology Lens: A Nationally Representative Study." Development and Psychopathology 24(2): 1-17.

Miller, Portia, Daphne Henry, and Elizabeth VotrubaDrzal. 2016. "Strengthening Causal Inference in Developmental Research." Child Development Perspectives 10(4): 275-80.

Miller, Portia, and Elizabeth Votruba-Drzal. 2017. “The Role of Family Income Dynamics in Predicting Trajectories of Internalizing and Externalizing Problems." Journal of Abnormal Child Psychology 45(3): 543-56.

Nepomnyaschy, Lenna, Allison Dwyer Emory, Kasey J. Eickmeyer, Maureen R. Waller, and Daniel P. Miller. 2021. “Parental Debt and Child WellBeing: What Type of Debt Matters for Child Outcomes?" RSF: The Russell Sage Foundation Journal of the Social Sciences 7(3): 122-51. DOI: 10 .7758/RSF.2021.7.3.06. 
Oliver, Melvin L., and Thomas M. Shapiro. 1995. Black Wealth/White Wealth: A New Perspective on Racial Inequality. New York: Routledge.

Orr, Amy J. 2003. "Black-White Differences in Achievement: The Importance of Wealth." Sociology of Education 76(4): 281-304.

Palacios-Barrios, Esther E., and Jamie L. Hanson. 2019. “Poverty and Self-Regulation: Connecting Psychosocial Processes, Neurobiology, and the Risk for Psychopathology." Comprehensive Psychiatry 90(1): 52-64.

Peterson, James L., and Nicholas Zill. 1986 “Marital Disruption, Parent-Child Relationships, and Behavior Problems in Children." Journal of Marriage and the Family 48(2): 295-307.

Pfeffer, Fabian T. 2018. “Growing Wealth Gaps in Education." Demography 55(3): 1033-68.

Pfeffer, Fabian T., and Robert F. Schoeni. 2016. “How Wealth Inequality Shapes Our Future." RSF: The Russell Sage Foundation Journal of the Social Sciences 2(6): 2-22. DOI: 10.7758/RSF.2016 .2.6.01.

Phillips, Meredith, Jeanne Brooks-Gunn, Greg J. Duncan, Pamela Klebanov, and Jonathan Crane. 1998. “Family Background, Parenting Practices, and the Black-White Test Score Gap." In The Black-White Test Score Gap, edited by Christopher Jencks and Meredith Phillips. Washington, D.C.: Brookings Institution Press.

Rauscher, Emily, and William Elliott. 2016. “Wealth as Security: Growth Curve Analyses of Household Income and Net Worth During a Recession." Journal of Family and Economic Issues 37(1): 2941.

Ream, Robert K., and Michael A. Gottfried. 2019. "Household Wealth and Adolescents' SocialEmotional Functioning in Schools." Social Science Research 83 (September). Available online July 2. DOI: 10.1016/j.ssresearch.2019.06.007.

Reardon, Sean F. 2011. “The Widening Academic Achievement Gap Between the Rich and the Poor: New Evidence and Possible Explanations." In Whither Opportunity? Rising Inequality, Schools, and Children's Life Chances, edited by Greg J. Duncan and Richard J. Murnane. New York: Russell Sage Foundation.

Royston, Patrick. 2005. "Multiple Imputation of Missing Values: Update of Ice." The Stata Journal 5(4): 527-36.

Saez, Emmanuel. 2017. "Income and Wealth Inequal- ity: Evidence and Policy Implications." Contemporary Economic Policy 35(1): 7-25.

Shanks, Trina R. 2007. “The Impacts of Household Wealth on Child Development." Journal of Poverty 11(2): 93-116.

Shanks, Trina R., and Mesmin Destin. 2009. "Parental Expectations and Educational Outcomes for Young African American Adults: Do Household Assets Matter?" Race and Social Problems 1(1): 27-35.

Shapiro, Thomas M. 2005. The Hidden Cost of Being African American: How Wealth Perpetuates Inequality. New York: Oxford University Press.

Shaw, Daniel S., Elizabeth B. Owens, Joyce Giovannelli, and Emily B. Winslow. 2001. “Infant and Toddler Pathways Leading to Early Externalizing Disorders." Journal of the American Academy of Child and Adolescent Psychiatry 40(1): 36-43.

Shim, Soyeon, Jing J. Xiao, Bonnie L. Barber, and Angela C. Lyons. 2009. "Pathways to Life Success: A Conceptual Model of Financial WellBeing for Young Adults." Journal of Applied Developmental Psychology 30(6): 708-23.

Votruba-Drzal, Elizabeth. 2006. “Economic Disparities in Middle Childhood Development: Does Income Matter?" Developmental Psychology 42(6): 1154-67.

Wadsworth, Martha E., Gary W. Evans, Kathryn Grant, Jocelyn S. Carter, and Sophia Duffy. 2016. "Poverty and the Development of Psychopathology." In Developmental Psychopathology, 3rd ed., edited by Dante Cicchetti. New York: John Wiley \& Sons.

Weininger, Elliot B., Annette Lareau, and Dalton Conley. 2015. “What Money Doesn't Buy: Class Resources and Children's Participation in Organized Extracurricular Activities." Social Forces 94(2): 479-503.

Wolff, Edward N. 2017. “Household Wealth Trends in the United States, 1962 to 2016: Has Middle Class Wealth Recovered?" NBER working paper no. 24085. Cambridge, Mass.: National Bureau of Economic Research.

Yellen, Janet L. 2016. “Perspectives on Inequality and Opportunity from the Survey of Consumer Finances." RSF: The Russell Sage Foundation Journal of the Social Sciences 2(2): 44-59. DOI: 10.7758/RSF.2016.2.2.02.

Yeung, W. Jean, and Dalton Conley. 2008. “Black- 
White Achievement Gap and Family Wealth."

Child Development 79(2): 303-24.

Yeung, W. Jean, and Sandra L. Hofferth. 1998. “Fam-

ily Adaptations to Income and Job Loss in the

US." Journal of Family and Economic Issues 19(3): 255-83.

Zhan, Min. 2006. “Assets, Parental Expectations and
Involvement, and Children's Educational Performance." Children and Youth Services Review 28(8): 961-75.

Zhan, Min, and Michael Sherraden. 2003. "Assets, Expectations, and Children's Educational Achievement in Female-Headed Households." Social Service Review 77(2): 191-211. 